Research article

VERSITA

DOI: $10.2478 / \mathrm{rrlm}-2013-0038$

\title{
Mutation analysis of the MECP2 gene in Romanian females with Rett syndrome
}

\section{Analiza mutațiilor genei MECP2 la pacientele cu sindrom Rett din România}

\author{
Simona Dumitriu ${ }^{1}$, Enriko Klootwijk ${ }^{3}$, Naomi Issler ${ }^{3,4}$, Horia Stanescu $^{2,3}$, \\ Robert Kleta ${ }^{2,3,4,5}$, Maria Puiu ${ }^{1 *}$ \\ 1. University of Medicine and Pharmacy Victor Babes, Timisoara \\ 2. Neuroscience, Physiology and Pharmacology, University College London, London, UK \\ 3. Centre for Nephrology, University College London, Royal Free Hospital, London, UK \\ 4. Institute of Child Health, University College London, London, UK \\ 5. Great Ormond Street Hospital for Children, London, UK
}

\begin{abstract}
The discovery of the methyl-CpG binding protein 2 (MECP2) gene located on Xq28 as being involved in Rett syndrome (RTT) has been followed by a broad spectrum of phenotypes being associated with mutations in MECP2. The distribution of MECP2 mutations has been studied in many populations, but only recently in Romania. We started the first local study searching for MECP2 mutations using PCR (polymerase chain reaction) based methods and Sanger sequencing. We have investigated 9 patients, all girls, 7 with classical RTT and 2 with atypical RTT from the Western part of Romania. Mutation screening revealed 3 different mutations present in 4 patients and 5 nonpathogenic genetic variations. One of the frameshift mutations has not been previously described: c.225delG (p.P75fs). The detection rate for missense and frameshift mutations was $44 \%$. In this study we focused on a practical approach necessary for the molecular geneticist in the process of screening RTT patients for MECP2 mutations. The aim is to extend this protocol for screening MECP2 mutations in all cases of MECP2-related Disorders, to offer prenatal diagnosis, and subsequently complete it with techniques which can detect large rearrangements of this gene.
\end{abstract}

Keywords: MECP2 mutation, Rett syndrome, sequencing, protocol

\section{Rezumat}

Descoperirea genei methyl-CpG binding protein 2 (MECP2) situate pe cromozomul Xq28 ca fiind implicata in producerea Sindromului Rett (RTT) a fost urmata de asocierea unui spectru de fenotipuri cu mutatiile acestei gene. Distributia mutatiilor MECP2 a fost studiata in diverse populatii, doar recent acest studiu fiind ini-

*Corresponding author: Maria Puiu, University of Medicine and Pharmacy Victor Babes, E. Murgu Square, No.1, Timisoara

Phone: 0040745138917, E-mail: maria_puiu@umft.ro 
tiat in Romania. Am initiat primul studiu localizat pentru identificarea mutatiilor genei MECP2 utilizand PCR si secventiere Sanger. Am investigat 9 paciente, din zona de vest a tarii, 7 prezentand forma clasica de RTT si 2 prezentand forme atipice, provenite. Screeningul mutatiilor a relevat 3 mutatii diferite, prezente la 4 paciente si 5 variatii genetice nonpatogenice. Una dintre mutatile detectate, deletia unei nucleotide in pozitia 225 (c.225delG) пи a mai fost descrisa anterior. Rata de detectie a mutatiilor in studiul nostru a fost de 44\%. In aceast studiu ne-am centrat pe o abordare practica necesara geneticianului molecular in cadrul procesului de screening al mutatiilor genei MECP2 la pacientii cu RTT. Dezideratul nostru este de a extinde protocolul de screening al mutatiilor MECP2 la cazurile de tulburari asociate genei MECP2, de a oferi diagnostic prenatal, si de a-l completa cu alte tehnici care pot detecta rearanjamente ale genei MECP2.

Cuvinte cheie: mutatii, MECP2, sindrom Rett, protocol.

Received: $17^{\text {th }}$ September 2013; Accepted: $29^{\text {th }}$ October 2013; Published: $13^{\text {th }}$ November 2013.

\section{Introduction}

Rett syndrome (RTT) (OMIM 312750) is an X-linked dominant neurodevelopmental disorder (1) and a common cause of mental retardation in females with a worldwide prevalence of 1 in 10,000 15,000 (2). The clinical manifestations in the classical form of RTT are characterized by cognitive deterioration after a period of apparently normal development of 6-18 months, with loss of acquired skills such as language and hand usage and the development of autistic features, stereotypical hand wringing movements, gait ataxia and autonomic symptoms (3). The RTT population has proved to be a lot more heterogeneous phenotypically than originally thought. Atypical RTT variants are commonly observed alongside typical variants. The individuals with atypical RTT generally show less severe symptoms than those with classic RTT. A large spectrum of varieties has been clinically recognised with variable levels of impairment of hands use and gait motor control, less severe than classic RTT, also associated with retained, although atypical and telegraphic language, and milder mental retardation. Multiple cases have been categorized within three variants: the preserved speech variant/ Zappella variant (4), the congenital variant with delayed early development (5), and the early-onset seizures variant (6).

MECP2 mutations have been demonstrated to be the primary cause of RTT. De novo heterozygous mutations have been identified in $70-90 \%$ of the sporadic cases of RTT (7).

MECP2 mutations were implicated not only in the pathogenesis of classical RTT, but also in a large proportion of the cases of atypical RTT variants. A majority of the female cases with the preserved speech variant also have a mutations in $\operatorname{MECP} 2(8,9)$. In the congenital variant with delayed early development a mutation has been found in a fraction of $20-40 \%$ (7).

$M E C P 2$ is a four-exon gene located at the terminal end of the long arm of the X chromosome (Xq28), encoding a protein composed of 486 amino acids. MECP2 participates in transcriptional repression preventing unscheduled transcription of other genes by binding to methylated CG dinucleotides in some genes promoters (7).

$M E C P 2$ has two major functional domains: methyl-CpG-binding domain (MBD) and a transcriptional repression domain (TRD) (Figure 1). MBD is an 85-amino acids domain (amino acids 78-162) through which MECP2 binds preferentially to methylated DNA at $\mathrm{CpG}$ sites (10). TRD is a 104 amino acid transcriptional repression domain (amino acids 207310) which realizes the role of $M E C P 2$ in silencing of downstream genes by its interaction with the transcriptional repressor Sin3A, which in turn recruits HDACs (11). Two other motifs with specific functions have been described in addition to MBD and TRD. The first, lying 

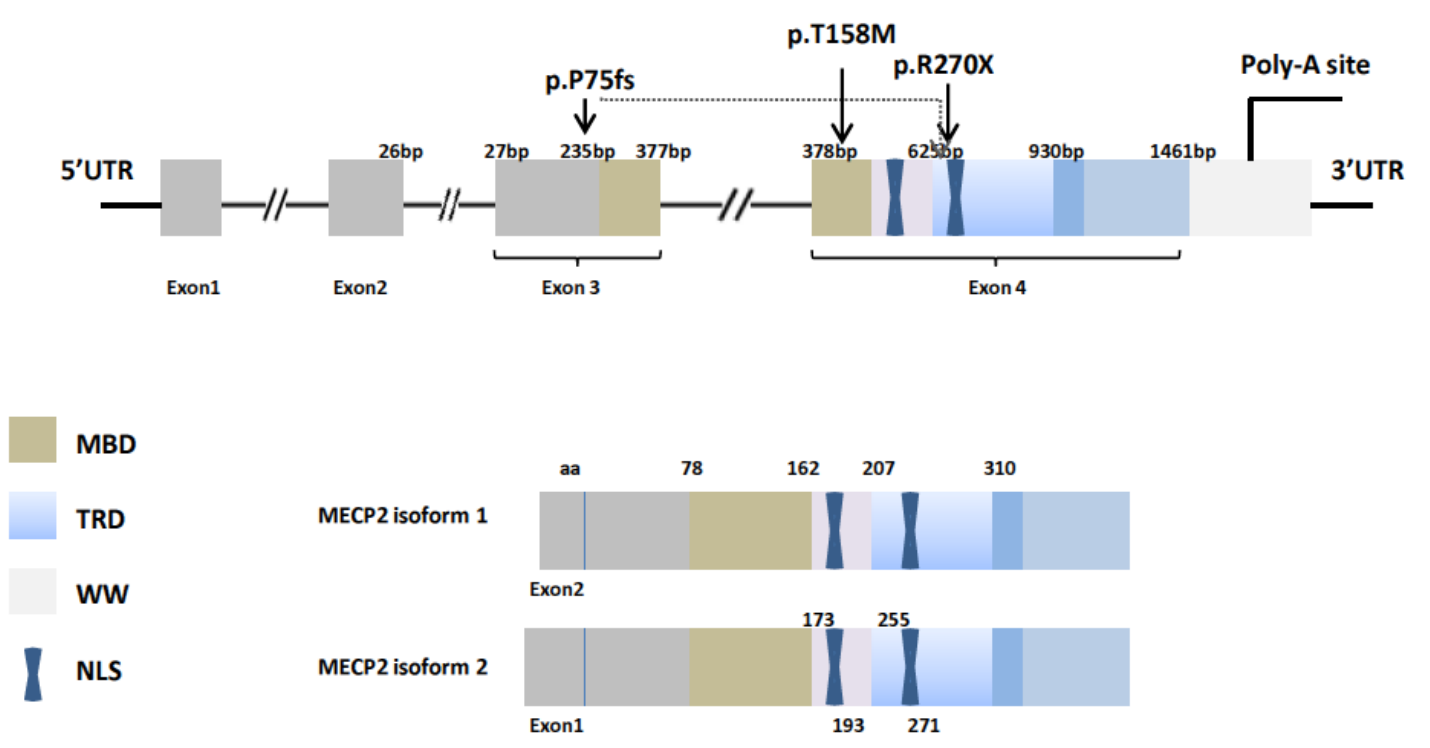

Figure 1. MECP2 splicing variants. The two main protein isoforms of 486 amino acids and 498 amino acids are produced by alternative splicing of the MECP2 transcript, differing in their $\mathrm{N}$-terminal regions, which are encoded by exon 2 of the gene in the case of isoform 1 and exon 1 in isoform 2 . The positions of the mutations identified in our female patients are indicated by arrows. MBD, methyl-CpG binding domain; NLS, nuclear localization signal; poly-A, polyadenylation; TRD, transcriptional repression domain.

within the TRD (amino acids 255-271), is the nuclear localization signal, which is sufficient for transportation in the nucleus (12). The last 63 amino acids, the carboxy-terminal segment of the gene, facilitates the binding of MECP2 to both naked DNA and the nucleosome DNA and increases protein stability (13).

Since the first report of the mutations in methyl-CpG binding protein 2 genes in patients with RTT, over 2000 mutations of MECP2 have been identified in patients with classical and atypical RTT. Missense mutations identified in $M E C P 2$ in patients with RTT were found in the functional domains, MBD and TRD, but also in the C-terminus region. In vitro studies have demonstrated that many missense mutations within the MBD have a significant impact on the affinity of $M E C P 2$ for methylated DNA (14). This function is retained if the mutation affects TRD, but the ability of $M E C P 2$ to repress transcription is impaired (15).

\section{Patients and methods}

\section{Patients}

We investigated 9 DNA samples from sporadic cases of female patients with an age median of 4.2 years, referred to the Genetic Department for clinical and molecular diagnosis. The recruitment criteria for these cases followed the RettSearch Consortium Guidelines for diagnostic criteria and nomenclature for both classical and variants form (3). Written informed consent was obtained. Personal and familial mental disabilities histories were obtained from parents and participating relatives.

\section{Molecular analysis}

We isolated total genomic DNA from peripheral blood using standard protocols: the WizardTM Genomic DNA purification kit (Promega Madison, WI, USA). DNA concentration was estimated using the NanoDrop ${ }^{\circledR}$ ND1000 Spectrophotometer. 
Table 1. Sequencing primer sequences for $M E C P 2$

\begin{tabular}{|c|c|c|}
\hline \multirow[t]{2}{*}{ Exon 11(17) } & $\mathrm{F}$ & $5^{\prime}-$ GCACTCGGTGCATCTGTGGACAGAG -3' \\
\hline & $\mathrm{R}$ & 5'- CATCCGCCAGCCGTGTCGTCCGAC -3' \\
\hline \multirow[t]{2}{*}{ Exon 2(1) } & $\mathrm{F}$ & 5'-TGTGTTTATCTTCAAAATGT-3', \\
\hline & $\mathrm{R}$ & 5'- GTTATGTCTTTAGTCTTTGG-3’, \\
\hline \multirow[t]{2}{*}{ Exon 3} & $\mathrm{~F}$ & $5^{\prime}-$ CTGGGGCCTTGCATGTGGTG -3' \\
\hline & $\mathrm{R}$ & 5'- GGTCATTTCAAGCACACCTG-3' \\
\hline \multirow[t]{10}{*}{ Exon 4} & $\mathrm{~F}$ & 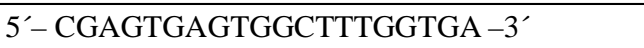 \\
\hline & $\mathrm{R}$ & 5'-ACAGATCGGATAGAAGACTC-3' \\
\hline & $\mathrm{F}$ & $5^{\prime}-$ CCACCCAGGTCATGGTGATC -3' \\
\hline & $\mathrm{R}$ & 5'- TGAGTGGTGGTGATGGTGGT-3' \\
\hline & $\mathrm{F}$ & $5^{\prime}-$ GCAGGAGACCGTACTCCCCATC -3' \\
\hline & $\mathrm{R}$ & 5'- GCTCTCCCTCCCCTCGGTGT-3' \\
\hline & $\mathrm{F}$ & $5^{\prime}$ - GCAGGAGACCGTACTCCCCATC -3' \\
\hline & $\mathrm{R}$ & 5'- GCTCTCCCTCCCCTCGGTGT-3' \\
\hline & $\mathrm{F}$ & $5^{\prime}-$ GGAGAAGATGCCCAGAGGAG -3' \\
\hline & $\mathrm{R}$ & 5'- CGGTAAGAAAAACATCCCCA -3' \\
\hline
\end{tabular}

Exon 1 being situated in a GC-rich region of the gene, the chosen length of the oligonucleotides was $25 \mathrm{nt}$.

The entire coding sequence of the gene, including exon/intron boundaries, was analyzed using PCR amplification and dideoxy Sanger sequencing.

We designed the following primer pairs using the available genomic sequence (NG_007107.1) (16) of the MECP2 locus to amplify the coding exons and the 3 UTR. The primer sequences are presented in Table 1.

PCR was performed with a mix containing 1.5 units Taq DNA polymerase, $10 \mathrm{mM}$ Tris- $\mathrm{HCl}, 50 \mathrm{mM} \mathrm{KCl}, 1.5 \mathrm{mM} \mathrm{MgCl} 2,0.5 \mu \mathrm{M}$ of forward and $0.5 \mu \mathrm{M}$ reverse primer, $0.2 \mathrm{mM}$ dNTP and stabilizers. ReadyMixTaq PCR Reaction Mix with $\mathrm{MgCl} 2$ (Sigma-Aldrich Biotechnology LP) was used for exons 2, 3 and 4. For the amplification of exon 1 and of the adjacent intronic regions the optimization of the PCR protocol implied the use of the same reaction volume and a GC-rich solution with the end concentration of 2 units of FastStart Taq DNA polymerase, $2 \mathrm{mM} \mathrm{MgCl}_{2}, 1 \mu \mathrm{M}$ of forward and $1 \mu \mathrm{M}$ reverse primer, $0.2 \mathrm{mM} \mathrm{dNTP}, 10 \mathrm{mM}$ Tris- $\mathrm{HCl}, 50 \mathrm{mM} \mathrm{KCl}$, dNTP and stabilizers provided by FastStart Taq DNA polymerase dNTPack ${ }^{\circledR}$ (Roche Applied Science).
In order to generate sufficient amounts of the desired product we optimized the cycling conditions additional to the optimization of the PCR mix adapted to the different regions of the gene. PCR cycling protocols are listed in Table 2.

Amplicons were verified by gel electrophoresis. DNA fragments were recovered with the High Pure PCR Product Purification Kit following instructions (Roche Applied Science).

For sequencing, the amplified products were denatured at $96^{\circ} \mathrm{C}$ for $20 \mathrm{sec}$, annealed at $50^{\circ} \mathrm{C}$ for $20 \mathrm{sec}$ and extended at $60^{\circ} \mathrm{C} 4 \mathrm{~min}$ for 30 cycles, using the same primers pairs as for the PCR reaction. After the sequencing reactions, the mixture of fragments was separated by capillary gel electrophoresis at $450-500 \mathrm{~V}$ on polyacrylamide gel, the fluorophore's wavelength being detected by the spectrograph. We have used Beckman Coulter CEQ $^{\mathrm{TM}} 8000$ Genetic Analysis System ${ }^{\circledR}$ (Beckman Coulter, Inc.) All of the products were sequenced in forward and reverse reactions. The sequence analysis was performed using a CEQ8000 capillary sequencer (Beckman Coulter, Inc.).

All the mutations and sequence variants are described according to the HUGO approved nomenclature (17) in Table 3. The reference se- 
Table 2. PCR cycling conditions for $M E C P 2$

\begin{tabular}{|c|c|c|c|c|c|}
\hline & & Exon 1 & Exon 2 & Exon 3 & Exon 4 \\
\hline Denaturatio & & $94^{\circ} \mathrm{C}$ for $7 \mathrm{~min}$ & $95^{\circ} \mathrm{C}$ for $5 \mathrm{~min}$ & $94^{\circ} \mathrm{C}$ for $4 \mathrm{~min}$ & $94^{\circ} \mathrm{C}$ for $4 \mathrm{~min}$ \\
\hline \multirow{3}{*}{35 cycles } & Denaturation & $95^{\circ} \mathrm{C}$ for $1 \mathrm{~min}$ & $95^{\circ} \mathrm{C}$ for $1 \mathrm{~min}$ & $94^{\circ} \mathrm{C}$ for $1 \mathrm{~min}$ & $94^{\circ} \mathrm{C}$ for $1 \mathrm{~min}$ \\
\hline & Annealing & $65^{\circ} \mathrm{C}$ for $1 \mathrm{~min}$ & $50^{\circ} \mathrm{C}$ for $1 \mathrm{~min}$ & $64.6^{\circ} \mathrm{C}$ for $1 \mathrm{~min}$ & $55-60^{\circ} \mathrm{C}$ for $1 \mathrm{~min}$ \\
\hline & Elongation & $72^{\circ} \mathrm{C}$ for $1 \mathrm{~min}$ & $72^{\circ} \mathrm{C}$ for $1 \mathrm{~min}$ & $72{ }^{\circ} \mathrm{C}$ for $1 \mathrm{~min}$ & $72^{\circ} \mathrm{C}$ for $1 \mathrm{~min}$ \\
\hline Extension & & $72{ }^{\circ} \mathrm{C}$ for $2 \mathrm{~min}$ & $72{ }^{\circ} \mathrm{C}$ for $2 \mathrm{~min}$ & $72^{\circ} \mathrm{C}$ for $2 \mathrm{~min}$ & $72^{\circ} \mathrm{C}$ for $2 \mathrm{~min}$ \\
\hline
\end{tabular}

Table 3. Summary of results for MECP2 sequencing

\begin{tabular}{|c|c|c|c|c|c|c|}
\hline Patient & \multicolumn{3}{|c|}{ Genetic modification } & \multirow{2}{*}{$\begin{array}{l}\begin{array}{l}\text { Involved functional } \\
\text { domain }\end{array} \\
\text { TRD, NLS, WW }\end{array}$} & \multirow{2}{*}{$\frac{\text { Age }}{5 y}$} & \multirow{2}{*}{$\begin{array}{l}\text { RTT type } \\
\text { Classic }\end{array}$} \\
\hline 1 & c. $808 \mathrm{C}>\mathrm{T}(26)$ & p.R270X & Frameshift & & & \\
\hline 2 & c. $1562 \mathrm{G}>\mathrm{A}$ & & 3'UTR & - & $3 y$ & Congenital variant \\
\hline 3 & c. $377+58 \mathrm{C}>\mathrm{T}$ & & Intronic variant & - & $7 y$ & Classic \\
\hline 4 & c.225delG & p.P75fs & Frameshift & TRD, NLS, WW & $8 y$ & $\begin{array}{l}\text { Preserved speech } \\
\text { variant }\end{array}$ \\
\hline 5 & c. $473 \mathrm{C}>\mathrm{T}(27)$ & p.T158M & Missense & MBD & $4 y$ & Classic RTT \\
\hline 6 & c. $378-88 \mathrm{C}>\mathrm{G}$ & & Intronic variant & - & $4 y$ & Classic RTT \\
\hline 7 & $\begin{array}{l}\text { c. } 473 C>\mathrm{T}(28) \\
\text { c. } 602 \mathrm{C}>\mathrm{T}(29)\end{array}$ & $\begin{array}{l}\text { p.T158M } \\
\text { p.A201V }\end{array}$ & $\begin{array}{l}\text { Missense } \\
\text { SNP rs61748381 }\end{array}$ & MBD & $16 y$ & Classical RTT \\
\hline 8 & WT & - & - & - & $3 y$ & Classic RTT \\
\hline 9 & WT & - & - & - & $3 y$ & Classical RTT \\
\hline
\end{tabular}

New mutations are presented in bold.

MBD: methyl-CpG-binding domain, TRD: translation repression domain, NLS: nuclear localization signal, WW domain binding region, SNP: single nucleotide polymorphism

quence used for $M E C P 2$ was NG_007107.1 for the coding sequence (16).

\section{Results and discussion}

When interpreting Sanger sequencing electropherograms of $M E C P 2$, the occurrence of two overlapping peaks of fluorescence signals suggests heterozygosity in the concerned patient at a given position. The derived forward and reverse sequences were aligned to the reference sequence version (GRCh37/hg19) using the BLAT tool of the UCSC Human Genome Browser (18). Known variants were identified based on UCSC's dbSNP137 variation \& repeat track (19).

We have analyzed the samples from Romanian RTT patients for mutations in the coding region of the $M E C P 2$ gene. All patients but two showed classic symptoms of RTT, according to the accepted clinical criteria (3).

Two atypical RTT variants were also described: one preserved speech variant (Zapella variant) in patient 4 and one congenital variant in patient 2 .

In two of the patients in our study we identified a missense mutation replacing a $\mathrm{C}$ with a T at nucleotide 473 (c.473C > T, p.T158M) (Figure $2 A$ ). T158M is one of the most frequently described mutations in classical RTT, being identified in almost $10 \%$ of the cases in the literature. Replacement of threonine, a hydrophobic amino acid, with a polar amino acid, methionine is affecting the C-terminal stretch of MBD (Figure 1).

The change of the secondary structure observed in this case is less important than the one observed for the other mutant forms of $M E C P 2$. It 
A
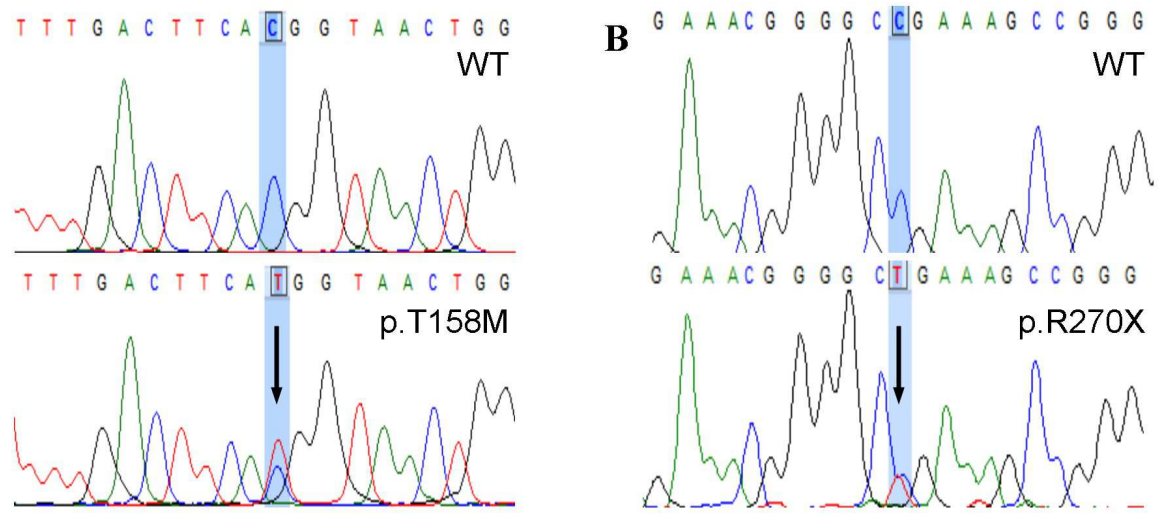

C

GCCCCGGCTGTGCC]GGAACTTCTGCCTCCCCCAAACAGCGGCGCTCCATCAT

WT

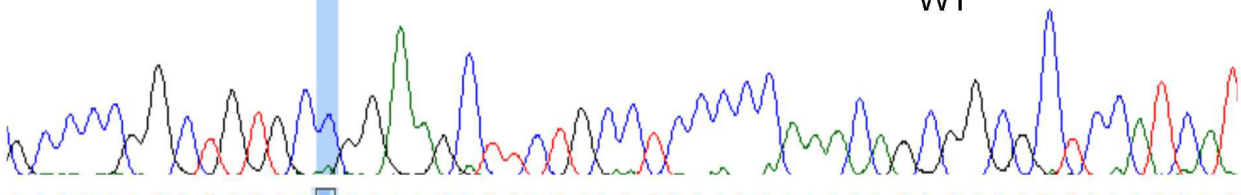

GCCCCGGCTGTGCDGGAAGCTTCTGCCTCCCCCAAACAGCGGCGCTCCATCA T

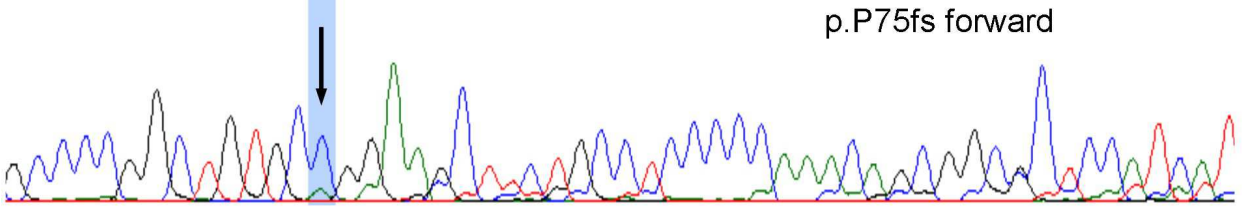

GCAGAAGCTTCCGGCACAGCCGGGGCGGAGCCTGACCCTTCTGATGTCTCTG

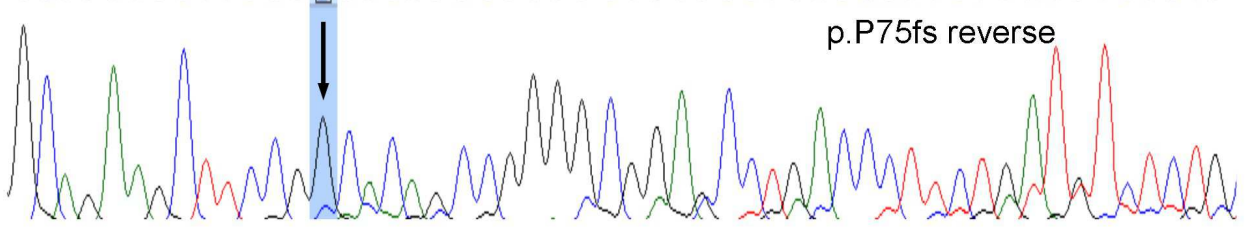

Figure 2. A,B: Original sequencing traces showing heterozygous mutations in MECP2 (lower traces) and of healthy controls (upper traces). Mutations indicated by arrows. C: the heterozygous deletion occurring on one allele throws the alignment of the two allele sequences; the two sequences, prior the deletion being in alignment (WT), changed from one sequence to two overlapping sequences both in the forward and reverse sequencing. The position of the deleted nucleotide indicated by arrows. WT-wild type

has been suggested that the hydrophobic residues placed in the hairpin loop play a role in stabilizing the orientation of the hairpin relative to the rest of the molecule (20). Mutant T158M-MBD was proven to have only a two-fold decrease of its selectivity for methylated DNA compared with the wild-type MECP2 (14).
The impact of this mutation has been studied by comparison with the Mecp $2 \mathrm{~T} 158 \mathrm{~A} / \mathrm{y}$ variant in a Mecp2 mouse model, which showed that another T158 mutation, threonine to alanine change, causes reduction in the affinity of Mecp2 for methylated DNA and decreases Mecp2 protein expression in vivo. 
The same effect on Mecp2 protein levels was described for T158M and confirmed using fibroblasts obtained from a female RTT patient carrying $M E C P 2$ T158M mutation. These data revealed two consequences of the T158M mutation: impairing $M E C P 2$ binding to DNA and decreasing $M E C P 2$ protein stability (21).

Another mutation identified in one patient is a previously described frameshift deletion (22) occurring in a (CCACC) rich region, c.808C $>\mathrm{T}$ (Figure 2B). Given the interest raised by the severe clinical impact of this mutation, studies have shown that R270X mouse exhibited also the severe early-onset disease, confirming the crucial importance of the R270 region for Mecp2 function.

MECP2 has three AT-hook-like domains in a 250 amino acid stretch, the second one containing amino acids 265-272, affected by R270X (Figure 1) (23). The role of the AThook-like domains is to bind to AT-rich DNA regions. This mutation leads to a loss of function of AT-hook-like 2 domain.

$M E C P 2$ first binds methylated DNA through MBD and second, for an efficient binding to the A/T-rich motif adjacent to methylated CpG dinucleotides, requires AT-hook-like domains (24) in order to realize chromatin packing. Truncated MeCP2-R270X leads to a loss of function of the AT-hook-like 2 domain causing the loss of MECP2 ability to maintain chromatin order and to act as transcription repressor. The effect of the mutations in this region on chromatin organization impacts the normal synaptic function and neuronal response (25).

Sequence analysis for patient 4 identified a heterozygous frameshift mutation: deletion of 1 bp at position 225: c.225delG (p.P75fs) (Figure $2 C$ ). Since no other variant was identified in the patient besides this deletion we hypothesized that this $\mathrm{G}$ deletion was also pathogenic. The novel mutation c.225delG described here, causes a frameshift and a premature stop at the 224 codon after 48 amino-acids. If the mRNA would be translated, the resulting protein would lack functional domains TRD, NLS and WW.
To our knowledge, data published until now show that patients with mutations in the N-terminal regions of $M E C P 2$ display a milder phenotype, usually associated with the preserved speech variant. Patients presenting this variant have better function overall. The clinical phenotype of these girls presents less dominating hand stereotypes, with a later age of onset, better use preserved speech and better gait control. The autonomic symptoms are also less common (26). This mutation affecting an amino-acid from the N-terminal region of MECP2, inducing a stop codon in TRD after 48 amino-acids may explain the atypical phenotype in our patient, with the presence of a telegraphic expressive language and retained ability to walk.

We detected variations located on noncoding regions of $M E C P 2$. Novel identified polymorphisms, c. $377+58 \mathrm{C}>\mathrm{T}$, c. $378-78 \mathrm{C}>\mathrm{T}$ and c. $378-84 \mathrm{C}>\mathrm{G}$ affect the +58 nucleotide of the 3 ' splicing site of the exon 3 , and the -78 and -84 nucleotides in the $5^{\prime}$ splicing site of exon 4, respectively, their potential impact on the protein level being unknown. In the same patients a pathogenic variant has not been identified in the coding sequence of MECP2. The implication of these polymorphisms for the phenotypic variability or susceptibility for RTT in this population is to be analyzed further.

The selection of patients according to strict clinical criteria are reported to lead to a high likelihood of finding a mutation in the MECP2 coding region, nearly to $90 \%$ when applied to large series (27). In smaller groups this is situated in a broad interval between 35 and $77 \%$ of cases (27). In our study, we report the identification of mutations in the coding sequence of $M E C P 2$ in $44 \%$ of the investigated cases. Given that RTT diagnosis and categorization of the form in concordance with the criteria is still difficult in stages previously to the stabilization phase, we consider that our study reported a positive correlation between molecular diagnosis and clinical diagnosis in an early phase.

Given that the screening for $M E C P 2$ mutations using sequencing of the coding re- 
gion and the flanking area of the gene did not report mutations in some of the patients with classical RTT and with the atypical congenital variant we consider that a search for large genomic rearrangements of $M E C P 2$ will be the next recommended step for molecular diagnosis in these patients. Literature data have previously described that large rearrangements of the MECP2 gene were identified in around $37 \%$ of classic and $7 \%$ of atypical RTT patients which previously tested negative for a mutation in the coding region (28).

The results of our study reflect the fact that precise definition of the phenotype increases the likelihood of obtaining a higher yield by genotyping. Our protocol aims to adapt a complex, time-consuming and expensive protocol for the sequencing of the entire MECP2 gene, by creating the advantage of quick and less expensive diagnosis.

Given that at least $85 \%$ of the mutations discovered in RTT patients were found to affect exon 3 and exon 4 of the gene, no mutation being found to affect exon 2 , we recommend that the sequencing protocol should cover the two main functional domains of $M E C P 2$, by sequencing exons 3 and 4 , and subsequently, if the genotyping results do not correlate to the phenotype to continue with exons 1 and 2 .

Our data provide a contribution towards understanding the Romanian population genetic characteristics and genotype phenotype correlation at the level of $M E C P 2$ gene. Research should be further developed in order to elucidate a mutation spectrum at the population level and connect it with existing databases within the Eastern European or Western regions.

\section{Acknowledgements}

This research was partly carried out with the financial support of the European Social Fund - project 88/1.5/S/56949. We also thank Dr. Anca Sabau for participating in the clinical screening of the patients.

\section{Electronic Database Information}

Accession numbers and URLs for the data presented herein are as follows:

Online Mendelian Inheritance in Man (OMIM), http://www.ncbi.nlm.nih.gov/Omim/ (for RTT [MIM 312750] and MeCP2 [MIM 300005]).

NCBI reference sequence for MECP2, http://www.ncbi.nlm.nih.gov/gene/4204 (NG_007107.2).

\section{References}

1. Amir RE, Van dV, I, Wan M, Tran CQ, Francke U, Zoghbi HY (1999). Rett syndrome is caused by mutations in X-linked MECP2, encoding methyl-CpG-binding protein 2. Nat Genet 23: 185-188.

2. Hagberg B, Aicardi J, Dias K, Ramos O (1983). A progressive syndrome of autism, dementia, ataxia, and loss of purposeful hand use in girls: Rett's syndrome: report of 35 cases. Ann Neurol 14: 471-479.

3. Neul JL, Kaufmann WE, Glaze DG, Christodoulou J, Clarke AJ, Bahi-Buisson N, et al. (2010). Rett syndrome: revised diagnostic criteria and nomenclature. Ann Neurol 68: 944-950.

4. Zappella M (1992). The Rett girls with preserved speech. Brain Dev 14: 98-101.

5. Rolando S (1985). Rett syndrome: report of eight cases. Brain Dev 7: 290-296.

6. Hanefeld F (1985). The clinical pattern of the Rett syndrome. Brain Dev 7: 320-325.

7. Shahbazian MD, Zoghbi HY (2002). Rett syndrome and MeCP2: linking epigenetics and neuronal function. Am J Hum Genet 71: 1259-1272.

8. De BC, Zappella M, Hayek G, Meloni I, Vitelli F, Bruttini M, et al. (2000). Preserved speech variant is allelic of classic Rett syndrome. Eur J Hum Genet 8: 325330.

9. Zappella M, Meloni I, Longo I, Canitano R, Hayek G, Rosaia L, et al. (2003). Study of MECP2 gene in Rett syndrome variants and autistic girls. Am J Med Genet B Neuropsychiatr Genet 119B: 102-107.

10. Lewis JD, Meehan RR, Henzel WJ, Maurer-Fogy I, Jeppesen P, Klein F, et al. (1992). Purification, sequence, and cellular localization of a novel chromosomal protein that binds to methylated DNA. Cell 69: 905-914.

11. Nan X, Ng HH, Johnson CA, Laherty CD, Turner BM, Eisenman RN, et al. (1998). Transcriptional repression by the methyl-CpG-binding protein $\mathrm{MeCP} 2$ involves a histone deacetylase complex. Nature 393: 386-389.

12. Nan X, Tate P, Li E, Bird A (1996). DNA methylation specifies chromosomal localization of MeCP2. Mol Cell Biol 16: 414-421. 
13. Chandler SP, Guschin D, Landsberger N, Wolffe AP (1999). The methyl-CpG binding transcriptional repressor $\mathrm{MeCP} 2$ stably associates with nucleosomal DNA. Biochemistry 38: 7008-7018.

14. Ballestar E, Yusufzai TM, Wolffe AP (2000). Effects of Rett syndrome mutations of the methyl-CpG binding domain of the transcriptional repressor MeCP2 on selectivity for association with methylated DNA. Biochemistry 39: 7100-7106.

15. Yusufzai TM, Wolffe AP (2000). Functional consequences of Rett syndrome mutations on human MeCP2. Nucleic Acids Res 28: 4172-4179.

16. NCBI. http://www.ncbi.nlm.nih.gov/gene/4204 . 2013. 7-15-2013. Ref Type: Electronic Citation

17. HUGO. http://www.genenames.org/data/hgnc_data.php?hgnc_id=6990 . 2011. 7-15-2013. Ref Type: Electronic Citation

18. USCS genome browser. http://genome.ucsc.edu/cgibin/hgBlat?command=start . 2009. 7-15-2013. Ref Type: Electronic Citation

19. USCSdbSNP(137). http://genome.ucsc.edu/cgibin/hgTrackUi?hgsid=342271035\&c=chrX\&g=snp137-

Common . 2012. Ref Type: Electronic Citation

20. Ohki I, Shimotake N, Fujita N, Nakao M, Shirakawa M (1999). Solution structure of the methyl-CpG-binding domain of the methylation-dependent transcriptional repressor MBD1. EMBO J 18: 6653-6661.

21. Goffin D, Allen M, Zhang L, Amorim M, Wang IT, Reyes AR, et al. (2012). Rett syndrome mutation MeCP2 T158A disrupts DNA binding, protein stability and ERP responses. Nat Neurosci 15: 274-283.

22. Obata K, Matsuishi T, Yamashita Y, Fukuda T, Kuwajima K, Horiuchi I, et al. (2000). Mutation analysis of the methyl-CpG binding protein 2 gene (MECP2) in patients with Rett syndrome. J Med Genet 37: 608-610.

23. Baker SA, Chen L, Wilkins AD, Yu P, Lichtarge O, Zoghbi HY (2013). An AT-hook domain in MeCP2 determines the clinical course of Rett syndrome and related disorders. Cell 152: 984-996.

24. Klose RJ, Sarraf SA, Schmiedeberg L, McDermott SM, Stancheva I, Bird AP (2005). DNA binding selectivity of $\mathrm{MeCP} 2$ due to a requirement for $\mathrm{A} / \mathrm{T}$ sequences adjacent to methyl-CpG. Mol Cell 19: 667-678.

25. Nan X, Campoy FJ, Bird A (1997). MeCP2 is a transcriptional repressor with abundant binding sites in genomic chromatin. Cell 88: 471-481.

26. Cheadle JP, Gill H, Fleming N, Maynard J, Kerr A, Leonard H, et al. (2000). Long-read sequence analysis of the MECP2 gene in Rett syndrome patients: correlation of disease severity with mutation type and location. Hum Mol Genet 9: 1119-1129.

27. Kammoun F, de RN, Boespflug-Tanguy O, Vallee L, Seng R, Tardieu M, et al. (2004). Screening of MECP2 coding sequence in patients with phenotypes of decreasing likelihood for Rett syndrome: a cohort of 171 cases. J Med Genet 41: e85.

28. Ravn K, Nielsen JB, Skjeldal OH, Kerr A, Hulten M, Schwartz M (2005). Large genomic rearrangements in MECP2. Hum Mutat 25: 324. 